\title{
Breast Skin Necrosis After Methylene Blue Dye İnjection: Breast Image
}

Metilen Mavi Boya Enjeksiyonu Sonrası Meme Cildi Nekrozu:

Meme Görüntüsü

Arda Isık, Deniz Fırat, Kemal Peker, Abdullah Inal, İsmayil Yılmaz, Fehmi Celebi

Erzincan University, School of Medicine, General Surgery Department, Erzincan, Turkey

Yazışma Adresi / Correspondence: Arda Işık

Erzıncan Universitesi Tıp Fakültesi, Genel Cerrahi A:D., ERZiNCAN

E-mail: kararda@yahoo.com

Geliş Tarihi / Received : 08.01.2018 Kabul Tarihi / Accepted : 09.03.2018

\begin{tabular}{ll}
\hline Abstract & \\
\hline & $\begin{array}{l}\text { Sentinel lymph node dissection is the gold standard treatment for non-lymph node metastatic breast cancers. Here we present, a 41-year- } \\
\text { old woman with a BIRADS-5 mass in the left retroareolar area. After sentinel lymph node biopsy, she had breast skin necrosis. } \\
\text { This manuscript presented at 12th Breast Disease Congress. } \\
\text { ( Sakarya Med J 2018, 8(1):153-156) }\end{array}$ \\
Keywords & breast conserving surgery, methylene blue, skin necrosis \\
\hline
\end{tabular}

öz

Sentinel lenf nodu diseksiyonu, lenf nodu metastazı olmayan meme kanseri hastalarında altın standart tedavi yöntemidir. 41 yașinda BIRADS-5 retroareolar lezyonu olan hasta prezente edildi. Sentinel lenf nodu biyopsisi sonrası, meme cildi nekrozu gelişti.

Bu makale 12. Meme Hastalklarr kongresinde prezente edildi.

( Sakarya Tip Dergisi 2018, 8(1):153-156)

Anahtar meme koruyucu cerrahi, metilen mavisi, cilt nekrozu

Kelimeler 


\section{Introduction}

Sentinel lymph node dissection is the gold standard treatment for non-lymph node metastatic breast cancers.

\section{Case Report}

Here we present, a 41-year-old woman with a BIRADS-5 mass in the left retroareolar area. She underwent breast conserving surgery plus sentinel lymph node biopsy. On the fourth day postoperatively, necrosis was seen in both the dermis and subcutaneous layers (Figure 1-2), which were treated conservatively with daily wound dressings. On the 15 th day postoperatively, the necrosis diminished.

\section{Discussion}

In sentinel lymph node biopsy, dyes such as isosulfan blue or methylene blue are commonly used. The latter may cause cosmetic problems, which when severe, can cause necrosis. In such cases, debridement may be necessary ${ }^{1-2}$.

There is no conflict of interest among authors.

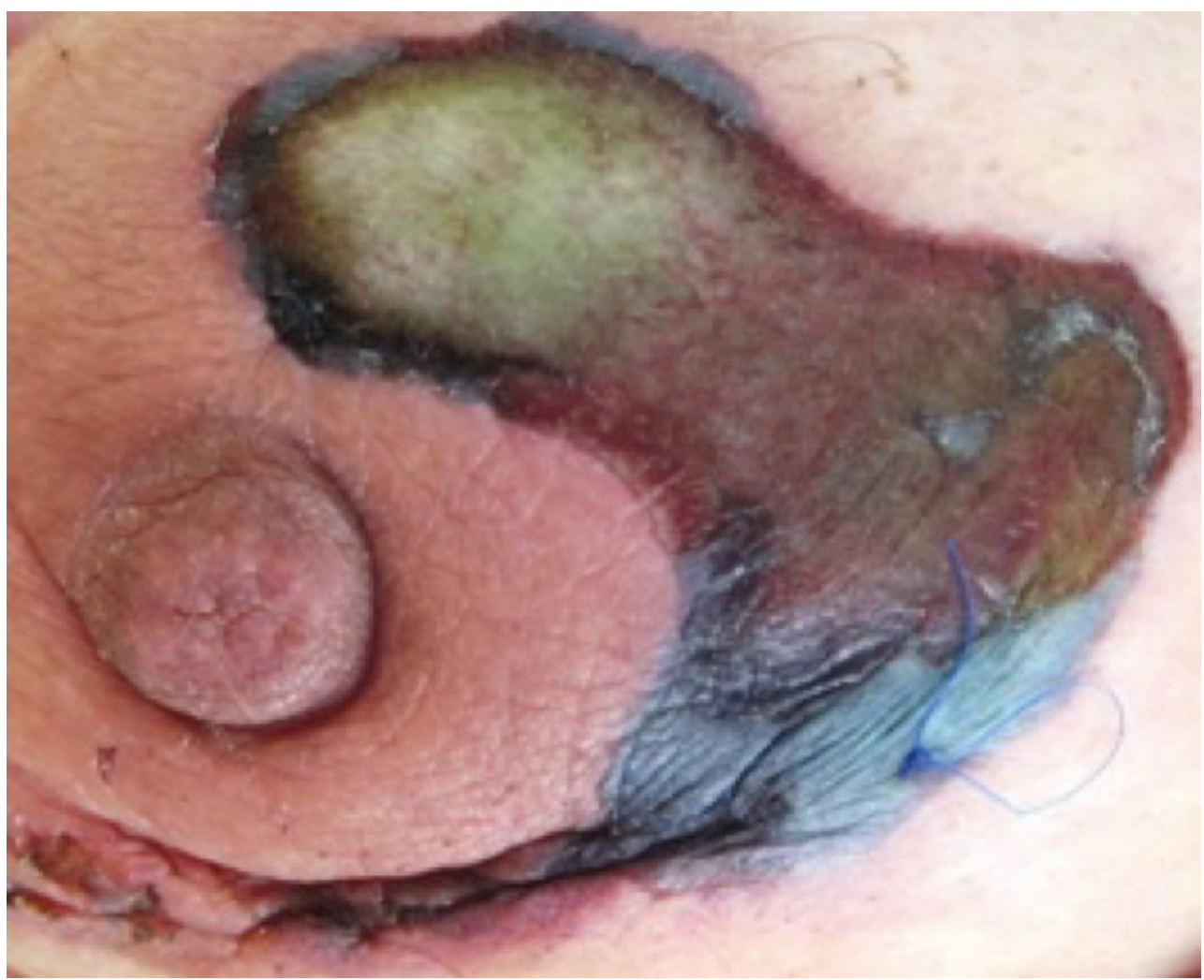

Figure 1: Necrosis at breast skin 


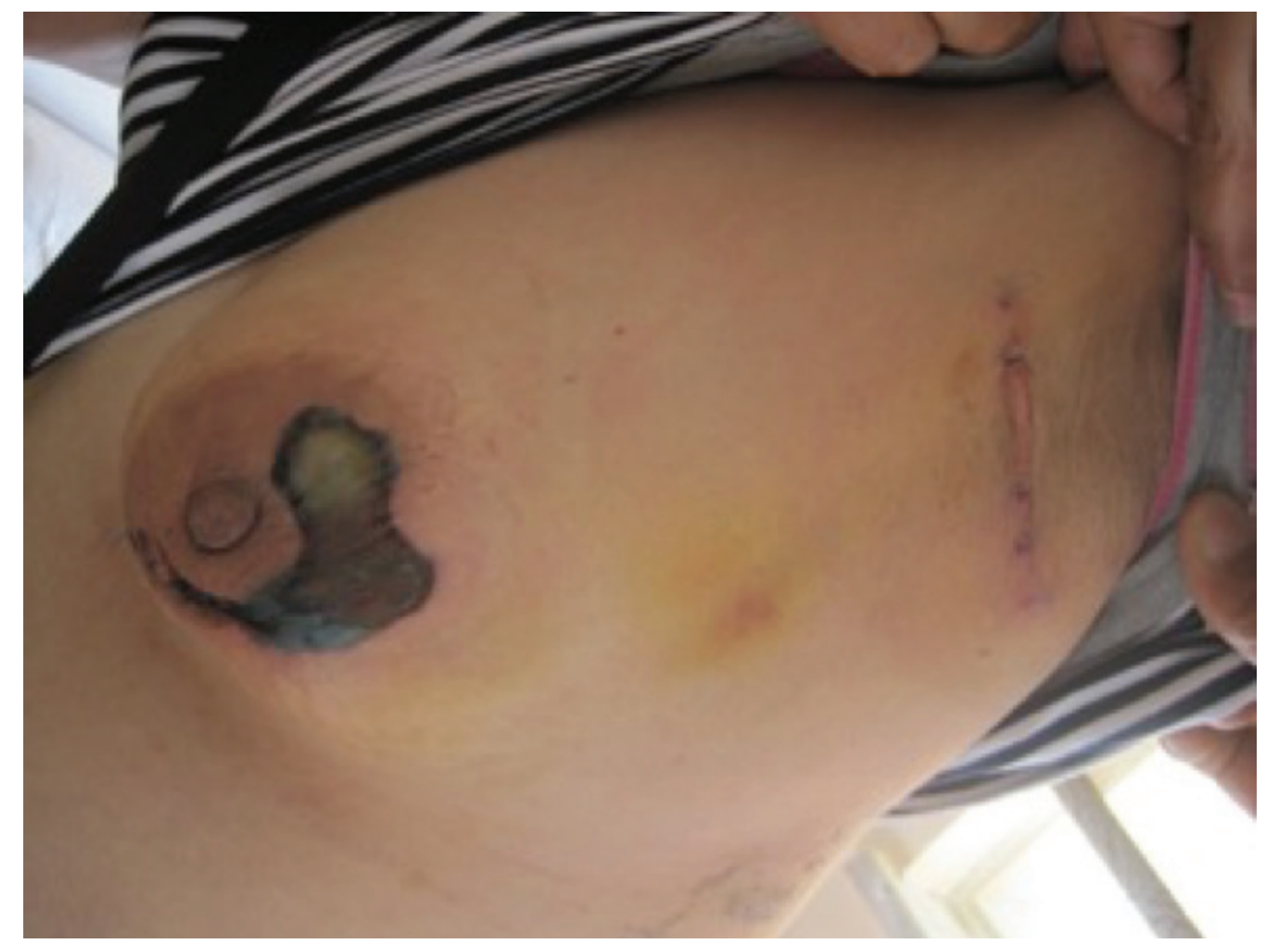

Figure 2: Necrosis at breast skin

Sakarya Med
J2018;8(1):153-156

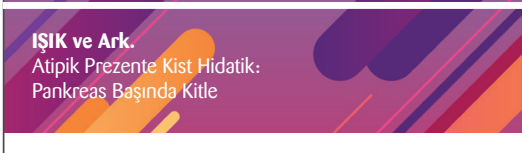

\section{ISIIK ve Ark.}

Pankreas Bașinda Kitle 
1. Reyes F, Noelck M, Valentino C, Grasso-Lebeau L, Lang J. Complications of methylene blue dye in breast surgery: case reports and review of the literature. J Cancer. 2010;2:20-5.

2. Angarita FA, Acuna SA, Cervera S, Torregrosa L, Tawil M. Meeting surgical necessities for sentinel lymph node biopsy in breast cancer: experience withmethylene blue in a Colombian hospital. Breast J. 2012;18:618-9. 